American Journal of Economics and Business Administration 1 (2): 150-159, 2009

ISSN 1945-5488

(C) 2009 Science Publications

\title{
Acceptance and Use of Strategic Processes in Developing Countries
}

\author{
Alev M. Efendioglu and A. Tugba Karabulut \\ ${ }^{1}$ University of San Francisco, School of Business and Management, \\ 2130 Fulton Street, San Francisco, CA 94117-1045, USA \\ ${ }^{2}$ Istanbul Commerce University, Faculty of Commercial Sciences. Selman-i Pak Cad. \\ 34672 Istanbul, Turkey
}

\begin{abstract}
Problem statement: The concept of strategy has become a major process in for-profit and not-for-profit organizations. These organizations have used the process to understand issues which they cannot control but have a significant impact on their success and use their limited resources and competencies to improve their competitive positions. The process was used in developed economies and primarily by businesses with large scale operations. The purpose of this study is to extend the previous findings by examining the nature and practice of strategic planning in a different environmental context, that of the developing transitional economy of Turkey. Approach: The literature review was conducted to explore the usage of strategic processes in developing countries. The research which includes 71 companies was also conducted. Our research sample was drawn from the Istanbul Chamber of Industry database which listed the top 500 manufacturing firms. The frequency distribution analyses were conducted to the data. Results: Our results clearly showed that the managerial skills and competitive processes used by the domestic organizations are evolving and will create significant competitive challenges for the new entrants into these transitory environments. The foreign owned firms adopt a broader and deeper repertoire of tools and techniques of strategic planning than do local firms. Conclusion: Even though the findings showed a significant increase in the importance and use of strategic tools and processes in Turkey, a transitional economy, they also showed that there are continuing major differences in the use of these same tools and processes between competing firms from a transitional economy Vs a developed economy. By identifying and documenting the levels of strategic process and the types of strategic tools employed by the companies in differing stages of transitory economies, we can develop a roadmap and incorporate this knowledge to educate and prepare the managerial talents in these economies.
\end{abstract}

Key words: Strategic planning, Turkey, strategic analysis tools, organizational capability, holding, transitional economy, developing country, strategic processes, mission statement, business, unit

\section{INTRODUCTION}

Even though the concept of strategy may have had its original underpinnings in the military and its war efforts, over many decades it has become a mainstay and a major process (organizational activity) in forprofit and not-for-profit organizations. These organizations have refined and used the process to understand issues which they cannot control but have a significant impact on their survival and success and use their limited resources and competencies to improve their competitive positions.

Over time, the topic has created controversies and its organizational value was questioned. During 1960s and 1970s most senior executives acknowledged strategic planning as "the one best way" to develop and implement strategies that would provide each business unit with a competitive edge. During early 1980s there was a reaction against strategic planning and it suffered a downturn in popularity and influence. Doubt was cast on the view that strategies are always explicitly and deliberately formulated. It was argued that strategies can emerge from the actions of the employees of the organization without any a priori intentions based on a grand design ${ }^{[1]}$ and the value of planning in turbulent environments was questioned ${ }^{[2]}$. Hayes and Abernathy especially criticized portfolio analysis as a tool that led managers to focus on minimizing financial risks rather

Corresponding Author: Alev M. Efendioglu, University of San Francisco, School of Business and Management, 2130 Fulton Street, San Francisco, CA 94117-1045, USA Tel: +1.415.422.6389 Fax: +1.415.422.2502 
than investing in new opportunities that required a longterm commitment of resources ${ }^{[3]}$.

During the 1990s, however, strategy regained some of its popularity and influence that it had previously lost. In 1996, Business Week heralded the return of strategic planning. One reason for this was the view that "there is a growing feeling that practical strategic advice can be based on sound deduction and systematic observation $^{[4]}$," The development of the resource based view of strategy also played a major role in this resurgence of practical strategic planning ${ }^{[5,6]}$. Whereas these observations were based on increased usage of strategic planning in United States, a similar conclusion was reached in United Kingdom by Glaister and Falshaw $^{[7]}$. Their analysis of the extent to which tools and techniques of the classical model of strategy formulation were adopted in a sample of UK firms and the views and attitudes towards strategic planning of senior executives in these firms were detailed in their article in Long Range Planning. Their conclusions were that the strategic planning was currently being perceived to be of benefit, it was going strong, companies could obtain benefits from strategic planning and that these benefits were apparent with the use of relatively unsophisticated tools and techniques. As a further support of this new popularity of use of strategic planning, Bain \& Company's Fourth Annual Survey of management tools and techniques showed that $89 \%$ of the surveyed international managers use strategic planning to drive success through their organizations ${ }^{[8]}$.

During 2007 additional concerns were voiced and there were questions as to its prevalence (use) in small businesses in developed economies and all types and sizes of businesses in developing or transitory economies. Small business owners constantly and consistently state that their decisions are influenced much more by their experiences and observations of their customer's behaviors (on what they learn from day-to-day contact with customers) and their reliance on gut feeling than formal, systematic approaches.

Until recently, the primary focus of researchers of strategic planning had been United States and developed economies of Europe. As the economy in United States and Great Britain developed and evolved, various models and methodologies were developed and serious discussions of these methodologies and concepts were conducted on improving competitiveness of businesses in these economies. Very little research was conducted to examine the understanding and usage of these strategic planning concepts and tools in developing countries and the organizations which form the foundations of these economic systems. One could argue that among the causes of this lack of research were semi-closed state of these economies, the dominant legal ownership (state owned) and the associated governance of majority of medium to largescale organizations and the lack of sophistication of the managers of these organizations. Furthermore, the structure of these economies did not present the same competitive issues which dominate open and developed economies and may not have necessitated the use of strategic planning to gain additional competitive advantages. Comments and declarations like "I can't even meet the demand and have a backlog, why should I worry about tomorrow?" were representative of the management philosophy of few decades ago and were very good indications of the existing level of competitive pressures in these semi-closed economies. Mintzberg $^{[9]}$ has argued that the strategy-making process is an ongoing process and its effectiveness is affected by the existence of uncertainty, which is a characteristic of its foundation. The relative stability of state controlled economies, in nations at the early stages of their transition from developing to developed, present less of a challenge for companies in their dealings with possible environmental uncertainties and there may not have been the same urgency for these firms to engage in strategic processes.

Last decade and a half has seen major developments in communication technologies and resulting globalization of all types of industries and business processes. The businesses from developed economies have extended their reach to all corners of the globe in search of cheaper costs and new markets, bringing a greater dynamism and heightened level of competitive behaviors to these previously fairly stable economic environments. Furthermore, the increased "Foreign Direct Investments" (FDI) and the associated ownership and governance of new and foreign based competitors have added new competitors, forcing the executives of the local enterprises to develop or acquire talent in their managerial ranks and increase their sophistication of the dynamic competitive forces of their business environments. Some countries which were considered undeveloped/developing have been impacted by these changes much more significantly than others. The governments of these countries have taken steps to use these developments as means to accelerating their economies' transition from an underdeveloped to a developed economy, while opening their local businesses to increased competition and forcing them to adjust their organizational processes to sustain themselves in unfamiliar dynamic environments and increased uncertainties. As evidenced by the World Economic Forum global competitiveness index, Turkey has moved from 71st (out of 131 
countries ranked) for 2005-2006-59 for 2006-2007 and to 53 for the 2007-2008. The sophistication of company operations and strategy ranking for 2007-2008 is 41 out of 127 countries ranked ${ }^{[10,11]}$. The World Economic Forum's annual Global Competitiveness Report evaluates the potential for sustained economic growth of over 130 developed and emerging economies and ranks them accordingly. It was first released in 1979.

Unfortunately, we have not been able to find more than a few comparative multi-national studies which have researched the acceptance and use of strategymaking processes and tools for strategic analysis. To provide additional insights into this topic, we decided to focus on large scale businesses in one of these developing economies. Because of their resource capabilities (strategy-making is a resource intensive process), we selected large businesses as our starting point. We hope to also study medium and small organizations at a later date. Therefore, the purpose of this study is to extend the previous findings by examining the nature and practice of strategic planning in a different environmental context, in economic environments which are going through a transition to a developed economy. Because we determined Turkey to be such a country (one that is transitioning to a developed country), we focused on the firms competing in this transitory environment. This context provides the novelty to our study, as most prior studies on the strategic planning process have examined evidence from firms in mature market economies. To extend our understanding of the process of strategy, we will briefly discuss why we consider and classify Turkey as a "transitional economy", review and discuss the few research studies and their findings conducted in similar economies and present the findings of our research study of top 500 companies in Turkey. This will help to generalize the previous findings and will be instructive in comparing the strategic planning processes of firms in a developed market economy and those located in a transitional economy. By identifying and documenting the levels of strategic process and the types of strategic tools employed by the companies in differing stages of transitory economies, we can develop a roadmap and incorporate this knowledge to educate and prepare the managerial talents in these economies.

Turkey's economy in transition: The characteristics of the Turkish economy make it an interesting case to examine the nature and role of the strategic planning process in its largest businesses. Since the early 1980s, government policies in Turkey have focused on developing a free market economy and have encouraged an outward-oriented export-led economic development strategy. Significant progress has been made in the liberalization of trade and investment policies and the pursuit of macroeconomic stability and economic growth.

This policy stance has also contributed to a substantial increase in inward Foreign Direct Investment (FDI) to Turkey. According to 2007 Direct Investment Report, published by the International Investors Association of Turkey, Turkey has climbed to 16th place among top FDI attracting countries in 2006, up from 22nd place in 2005, 37th place in 2004 and 53rd place in 2003. It was ranked 5th among the developing countries. The level of FDI inflows to Turkey has increased from an average of 853 million USD during the 1995-2000 period to 9.8 billion USD in 2005 and to 20.1 billion USD in 2006. As of first five months of 2007, FDI inflows reached 11 billion USD, reinforcing the predictions for FDI inflows of 25 billion USD and plus for the yearend. ${ }^{[13]}$. As another outcome of this increased FDI and transition of the Turkish economy, demand for translations into Turkish language has grown $36 \%$ over the last year, placing it at number 9 in the world after Chinese and Russian. Top six is composed of former Eastern Block countries which have joined or in the process of joining EU.

As another sign of transition and globalization, Turkish companies have also made significant investments outside Turkey, totaling 6.3 billion USD from January 2002 through August 2007. These investments totaled of 1.7 billion USD for 2006 and 1.856 billion for the first eight months of 2007, with Middle East countries, Egypt being on top, being the most favored investment locations. These investments have focused on petroleum products, financial services, textile, transportation and trade industries.

Over a decade ago, due to its high economic growth and rapidly growing population, the US Department of Commerce placed Turkey among the ten big emerging markets ${ }^{[12]}$. As the developments to date have shown, this classification was very much on target. Turkey's last five years' growth rate average of around $7 \%$ puts it into one of the world's best performing economies. Turkey ranked 22nd among the exporting countries and with $16 \%$ increase in exports during 2006, is on par with average export growth rates of global economies. Its exports to Europe have grown an average of $24 \%$ for the past three years and with $55 \%$ of the country's total exports, EU remains the nation's leading export market. At a press conference on November 1, 2007, Turkish Exporters Association (TIM) president and Turkish Minister of State announced that total exports for the twelve month period ending October 2007 was $25.74 \%$ higher 
compared to the previous same 12 month period. The total value of exports for October 2007 was USD 9.703 billion, $37.13 \%$ higher than October 2006. The exports for the first 10 months of 2007 were USD 85.423 billion, $24.86 \%$ increase over the same 10 month period of 2006. Turkey is ranked as 17th largest economy in the world and 6th largest in EU and has averaged and annual GDP growth of $7.4 \%$ year $^{-1}$ since 2002 .

By looking at the stages of the basic needs of a nation's population, Alfanso Martinez and Ronald Haddock, Vice Presidents of Booz Allen Hamilton Inc., a management consulting firm, present another approach in identifying transition economies and the nation's evolution from a developing one to an industrialized one. They identify and argue that a nation's basic needs evolve through survival (obtaining adequate food, shelter and clothing) to quality (seek better quality in food, shelter and clothing) to convenience (time-saving appliances and packaged foods) and finally to customization (goods and services which satisfy individual tastes and desires). According to these researchers, sub-Saharan Africa is in "survival" stage, China and India and Turkey are in "quality" stage, Eastern Europe and Latin America are in "convenience" stage and finally, North America, Japan and Western Europe are in the "customization" stage. Their model places Turkey and Brazil clustered around the start of the "convenience" stage.

All these different economic measures place Turkey at a very unique stage of economic development, as a country which is rapidly moving from a sheltered static economy to one which is dynamic and extremely competitive developed economy. Of course with this transition comes the additional competitive pressure for its home-grown private organizations and increased turbulence caused by foreign based competitors entering their markets. Furthermore, these Turkish firms' desires and attempts to enter foreign markets require these countries to educate and develop sophisticated managers, development and use of tools to understand these new markets and who can change their organizations to develop effective and efficient processes to be able to compete in these dynamic markets. Therefore, we expected that, given the significant changes in Turkey's economy and its pursuit of EU membership; a significant number of large Turkish firms will incorporate strategic process into their operations and they will demonstrate profound changes in the degree of use of these tools over the past 3-5 years.

Previous research: Unfortunately, our search for previous research studies on "strategic planning in developing countries" resulted in very few studies with a similar focus as ours. These studies were conducted in Bahrain (multiple industries), in Ghana (construction industry), in Saudi Arabia (multiple industries) and in Turkey (multiple industries).

The earliest of these studies was conducted in 1992 in Bahrain. In the study, researchers evaluated the use of ten of the most common strategic planning tools. They were SWOT analysis, the product life cycle, the experience curve, the growth-share matrix (BCG), the directional policy matrix, the PIMS study, gap analysis, perceptual mapping, financial analysis and SPACE analysis. The main conclusion of the study was that the planners in Bahrain had a very limited understanding and use of strategy concepts and strategic planning. The researchers further concluded that there was a significant need for the companies in this economy to become familiar with and use the numerous strategic planning tools to deal with the competitive challenges ${ }^{[13]}$.

The stated impetus for the 2003 Ghana study was the new volatile economic and political environments faced by the construction firms (civil engineering contractors and building contractors). The researcher's basic premise was that the adoption of free market economic polices in Ghana in recent years had created the need for large construction firms to undertake strategic planning to survive the potential onslaught of foreign construction companies. Furthermore, the researcher argued that even the small companies will have to focus on longer-term perspectives to face the downward "plundering" by large firms that get dislocated by market competition. The study results show that the acceptance of "strategic planning" is significantly different among the groups studied, being as low as $8.5 \%$ in some groups. Their findings also show that "civil engineering contractors" (more sophisticated owners with higher education) had a much greater acceptance of the practice than the "building contractors". The most striking differences are reported between locally owned firms (with almost no use of strategic processes and concepts) and the subsidiaries of foreign multinational firms (with significantly high level of usage of these concepts). The researcher explains these differences as being the result of "managerial technology transfer" from the foreign firms to local ones ${ }^{[14]}$.

We were able to reference two studies completed in Saudi Arabia. The earlier study was conducted during 2001 was coauthored by Ghamdi and Sami AlWhabi ${ }^{[15]}$ and is referenced in the later published study. The reference states that there was some awareness of and use of some form of strategic planning in 
companies in Saudi Arabia during 2001. However, because it was not published and only briefly referenced in the follow up study, we were not able to find additional details of this original study. The follow-up study by Ghamdi ${ }^{[15]}$ was quite broad and ambitious in its design and investigated the use of "SWOT analysis", "portfolio analysis", "analysis of critical success factors", "Porter's five-force analysis", "experience-curve analysis", "PIMS analysis", "what-if analysis", "stakeholders analysis", "value chain analysis", "benchmarking", "product life cycle analysis", "cognitive mapping" and "Delphi technique".

The researches concluded that the study results show different degrees of use of these tools in the 72 companies studied, with "analysis of critical success factors", "benchmarking" and "what-if analysis" being the most common and widely used. The researchers also reported that the strategic planning was most prevalent in 17 joint-venture firms and 29 firms with the largest revenues (turnover). Of the 72 firms under study, 7 firms (10\%) used these techniques regularly and 12 firms (17\%) used them somewhat regularly. A large percent $(45 \%)$ of the study participants reported that they did not use strategic planning at all.

The precursor to our study was a study by Dincer, Tatoglu and Glaister ${ }^{[16]}$, investigating the use of strategic planning tools by companies in Turkey. The study group was selected from a 2001 listing of companies in Turkey and represents the characteristics and activities of companies which are part of Turkish economy of 2001-2002 time period. As we have demonstrated in our earlier discussion of Turkish economy characteristics, the rate of transition of Turkish economy from a developing one to one that is developed has accelerated significantly during the last 4-5 years. Therefore, in preparing for the study, we expected that, because of the increased environmental turbulence and dynamics over time and competition from new and global companies, there would be a greater need, acceptance and use of strategic management tools and techniques by the companies currently operating in Turkey. Even though we do not know the exact firms they ${ }^{[16]}$ studied and cannot look at those firms for a direct comparison, our findings, by presenting the characteristics and the activities of Turkish companies in the current economy, will provide a comparative representation of change.

Dincer et $a l .^{[16]}$ study investigated attitudes towards a range of strategic planning issues and the use of a variety of tools and techniques including of strategic planning. Frequency of usage of a large number of most frequently used strategic planning tools/techniques was studied. Among them were economic forecasting models, strength, Weaknesses, Opportunities and Threats (SWOT) analysis, scenario construction and financial analysis of competitors. Their study group included 135 companies from both manufacturing and service sectors and they concluded that, across the board, there is relatively little use of a broad range of tools/techniques of strategic analysis and occasional use of limited set of analytical techniques. They identified the most frequently used strategic analysis as "economic forecasting models", "SWOT analysis", "scenario development" and "financial analysis of competitors". They attribute the relative frequent use of "economic forecasting models" and "scenario development" to Turkey's volatile economic conditions at the time of their study, with severe economic crises, chronic inflation and highly volatile exchange rates. The value chain analysis and portfolio matrices method were very seldom used.

\section{MATERIALS AND METHODS}

Our research sample was drawn from the Istanbul (Turkey) Chamber of Industry database which listed the top 500 manufacturing firms. The study questionnaire had different segments which focused on the governance (e.g., domestic and subsidiary) of the firm, whether the strategy development process was institutionalized or not (e.g., who is involved, how frequent) foundations of the process (e.g., mission statement and verifiable objectives) and the tools used in the process (e.g., SWOT and scenario development).

The survey questionnaire was mailed to the CEO of each company with a letter requesting that the CEO, or his/her senior executive in charge of strategy development within the organization, to complete it. The survey was also made available on the Internet, thus providing the respondents an option to return the paper copies or fill out the questionnaire electronically. The overall response rate was $14.2 \%$. Of the 71 returned responses, seven $(9.86 \%)$ were completed online. There were no duplicates between the paper and electronic returns.

The highest ranked respondent company was ranked as number 2 and the lowest was ranked as number 497. The company rankings were based on their 2006 annual manufacturing revenues (these firms had both manufacturing and non-manufacturing revenues), which ranged from highest TRY 5.606 billion (USD 4.745 billion) to lowest TRY 83.690 million (USD 70.846 million), with total revenues of TRY 6.456 billion (USD 5.541 billion) and TRY 95.294 million (USD 80.669million), of the same companies respectively. The number of employees 
ranged from highest 9,780 to lowest 66 with 1,197 as the average. (TRY was converted to USD for reference purposes. The conversion rate was USD 1 to TRY 1.18130, the effective rate on June 3, 2008.)

Over ten industries were represented in the sample and textile industry had the largest representation with nine firms. The respondent companies ranged from $12.68 \%$ (9 firms) classified as "single business" (95\% or more of their revenues coming from one business segment), $\quad 80.28 \% \quad$ (57 firms) classified as "dominant/focused business" (70-95\% of revenues coming from one business segment, to $7.04 \%$ (5 firms) classified as "multi-business" (with revenues less than $70 \%$ from any segment). All of the seventy-one firms were privately owned, $60(84.5 \%)$ of domestic origin (Turkish) and eleven (15.49\%) foreign-owned. The respondent firms ranged from wholly-owned independent companies to subsidiaries of divisions of large organizations.

\section{RESULTS AND DISCUSSION}

The objective of our study was two-fold. One, we wanted to find out what level of usage of strategic tools and processes permeated the companies in Turkish economy and two, whether there have been any changes in the level or intensity of the use of strategic tools and processes among Turkish firms over time.

Earlier studies implied that the closed local economies and management of the firms in these economies are not sophisticated enough to use strategy development and utilize market and competitive analysis tools to aid in their efforts. We expected that, given the significant changes in Turkey's economy and its pursuit of European Union (EU) membership; Turkish firms will incorporate these tools and strategic process into their operations and will demonstrate profound changes in the use of these tools over the past 3-5 years. Because there was an earlier study by Dincer et al. ${ }^{[16]}$, completed about five years earlier, we had an opportunity to compare and see if there have been any changes in the level or intensity of the use of strategic tools and processes among Turkish firms over time which would support our hypothesis.

As can be seen from Table 1, even though only eleven firms (approximately $15.50 \%$ of the sample) of the respondents were from foreign owned companies, we thought that it was enough to provide a comparative sample. However, unfortunately this sample size is not large enough for us to make definitive conclusions and present a broad based support for our discussion of our findings. Never the less, it provides a glimpse into possible differences between these two types of firms (domestic Vs foreign owned) operating in a dynamic and transitory economy. We were also interested to find out the level of influence the parent companies had on the strategies employed by their subsidiaries. As can be seen from Table 2, there is a much higher level of control by foreign companies over their subsidiaries as compared to domestic holding companies. In other words, the domestic holdings' subsidiaries have greater independence in developing competitive strategies as compared to foreign holdings' subsidiaries.

As can be seen from Table 3, even though there were also some variances between the domestic and foreign based companies in their strategic focus, the results were mixed and different items were valued by the domestic and foreign based firms. The two areas both types of firms seem to equally focus on and value were "quantitative objectives" and "organizational capabilities". This could be partially explained by the numerical and somewhat objective nature of these areas of interest. Because of their numerical base, they are relatively easy to establish, measure and monitor.

In all other areas, except for monitoring environmental changes, foreign based firms had a greater focus than the domestic firms. This could be due to the significant and accelerated changes in Turkey's economic, social, technological and regulatory environments and the learning process associated with this accelerated transition by the domestic firms.

Table 1: Governance (ownership status) $n=71$

\begin{tabular}{lllcll}
\hline $\begin{array}{l}\text { Country of } \\
\text { origin }\end{array}$ & $\begin{array}{l}\text { Division } \\
\text { subsidiary }\end{array}$ & $\begin{array}{l}\text { Holding } \\
\text { subsidiary }\end{array}$ & $\begin{array}{l}\text { Holding } \\
\text { division }\end{array}$ & $\begin{array}{l}\text { Parent with } \\
\text { divisions }\end{array}$ & $\begin{array}{l}\text { Parent without } \\
\text { divisions }\end{array}$ \\
\hline Domestic & 2 & 2 & 30 & 11 & 15 \\
Foreign & 1 & 2 & 8 & & \\
\hline
\end{tabular}

Table 2: Parent company's control over strategy (business unit independence) $\mathrm{n}=71$

\begin{tabular}{lll}
\hline & Most of the time (\%) & Always (\%) \\
\hline $\begin{array}{l}\text { Turkish holdings with business } \\
\text { units }(\mathrm{n}=11)\end{array}$ & 27.27 & 45.45 \\
$\begin{array}{l}\text { Business unit of a Turkish holding } \\
(\mathrm{n}=34)\end{array}$ & 35.29 & 47.06 \\
$\begin{array}{l}\text { Business unit of Foreign holding } \\
(\mathrm{n}=11)\end{array}$ & 36.36 & 63.64 \\
\hline
\end{tabular}

Table 3: Focus on strategic issues (high or very high) $\mathrm{N}=71$ $($ domestic firms $=60$ and foreign firms $=11$ )

\begin{tabular}{llll} 
& Domestic (\%) & \multicolumn{2}{l}{ Foreign (\%) } \\
& All respondents (\%) \\
\hline Quantitative objectives & 87.04 & 81.82 & 86.15 \\
Organizational capabilities & 85.19 & 81.82 & 84.62 \\
Organizational objectives & 81.48 & 100.0 & 84.62 \\
Changes in environment & 72.22 & 63.64 & 70.77 \\
Similar markets & 69.81 & 81.82 & 71.88 \\
Variations from prior plans & 66.67 & 90.91 & 70.77 \\
New markets & 44.44 & 63.64 & 56.92 \\
Contingency plans & 36.21 & 81.82 & 43.48 \\
\hline
\end{tabular}


After all, they are much more invested and their survival and success is much more dependent to this local economy (geographic concentration and focus). The foreign based companies at least have operations in two (maybe even more) different markets, their domestic market and their operations in Turkey. This diversity might provide them some cushion and hedging in their investments and asset allocations.

It is interesting to note that the subsidiaries of foreign firms are much more focused on "contingency plans", $81.82 \%$ rating it high or very high, as compared to the domestic firms (holdings or subsidiaries), only $36.31 \%$ rating it high or very high. Unfortunately, we did not explore this or other similar discrepancies between these two sets of firms (domestic vs. foreign owned). However, we can speculate on some alternative causes of the major focus discrepancy in "contingency planning". Among these alternative possibilities/reasons are "immediacy and intensity of competition" faced by these local market dependent firms, "better understanding of local issues" by the virtue of being homegrown and "degree of managerial sophistication" with the domestic firms still learning and developing sophisticated understanding of strategic issues. Similar focus related differences and similarities also existed when we looked at just the subsidiaries of domestic and foreign holding companies. Once again, since we did not have an opportunity to explore them in greater detail, we can only speculate on their reasons.

When we looked at focus of domestic holding companies with and without business units, the overall distribution of relative importance did not change. However, the domestic holding companies with business units were closer in their distribution of value they attach to the strategic issues as compared to domestic holding companies without business units.

As we stated earlier, one of the objectives of our study was to identify the role and use of strategic process and tools in companies operating in a dynamic and transitory economy, specifically firms operating and competing in Turkey, as it evolves from a developing to a developed country. As can be seen from Table 4, a significant number of domestic and foreign firms them have a strategic process in place, it is considered a very important organizational activity (by $86.26 \%$ of domestic firms and by $100.00 \%$ of foreign firms) and it is an annual process.

Even though there was a difference in the frequency of usage between domestic and foreign firms, as compared to the findings of similar studies conducted in Bahrain, Ghana and Saudi Arabia, these numbers are significantly higher than the percent of domestic firms participating in a similar process in those countries. With greater openness in the economy and the resulting increase in the intensity of competition, we wanted to see if there were any changes in the acceptance use strategic processes in Turkey, over time. When we compare our findings with a similar study conducted about five years ago by Dincer et al. ${ }^{[16]}$, we see a slight increase in the use and acceptance of strategic process.

Table 4: Organizational use of strategic process $\mathrm{N}=71$ (domestic firms $=60$ and foreign firms $=11$ )

\begin{tabular}{|c|c|c|}
\hline & Domestic (\%) & Foreign $(\%)$ \\
\hline Top management participation in the process ${ }^{1}$ & 79.43 & 100.00 \\
\hline Priority activity-conducted annually & 86.26 & 100.00 \\
\hline Priority activity-conducted annually & 70.71 & 81.75 \\
\hline Established set of procedures & 72.33 & 84.20 \\
\hline Mission statement & 83.33 & 100.00 \\
\hline Participation in the process by effected managers & 51.47 & 77.81 \\
\hline Quantified and verifiable written objectives & 71.91 & 100.00 \\
\hline
\end{tabular}

${ }^{1}$ : Very frequently and Always responses. All other responses are yesno responses

Table 5: Changes in the use of strategic process over time (2007 Vs 2002)

\begin{tabular}{lllll}
\hline & \multicolumn{2}{l}{ Domestic firms (\%) } & Foreign firms (\%) \\
& - $\begin{array}{l}\text { Earlier } \\
\text { Our findings }\end{array}$ & findings $^{1}$ & $\begin{array}{l}\text { Earlier } \\
\text { Our findings }\end{array}$ & findings $^{1}$ \\
\hline $\begin{array}{l}\text { Mission statement } \\
\begin{array}{l}\text { Quantified and } \\
\text { verifiable written } \\
\text { objectives }\end{array}\end{array}$ & 71.93 & 68.40 & 100.00 & 84.00 \\
${ }^{1}:$ Figures from the study of Turkish firms by Dincer & & \\
\end{tabular}

Table 6: Firms using strategic analysis tools (frequently or always) $\mathrm{N}=71$ (domestic firms $=60$ and foreign firms $=11$ )

\begin{tabular}{llll}
\hline & Domestic (\%) & Foreign (\%) & All respondents (\%) \\
\hline Critical success factors & 38.60 & 72.73 & 44.12 \\
Economic forecasting & 36.84 & 40.00 & 37.31 \\
SWOT analysis & 36.21 & 81.82 & 43.48 \\
What-if analysis & 21.05 & $30.00^{1}$ & 22.39 \\
Value chain analysis & 20.69 & 50.00 & 25.00 \\
Pest/step analysis & 19.30 & 45.45 & 23.53 \\
Core capabilities analysis & 17.24 & $50.00^{1}$ & 22.06 \\
Growth share matrix (BCG) & 15.52 & 55.56 & 20.90 \\
Porter's five forces analysis & 10.53 & $20.00^{1}$ & 11.94 \\
\hline ': Represents "frequently" responses. There & were no "always" \\
responses & \multicolumn{4}{l}{}
\end{tabular}

Table 7: Frequency of usage of strategic analysis tools $\mathrm{N}=71$ $($ domestic firms $=60$ and foreign firms $=11)$

\begin{tabular}{llll}
\hline & $\begin{array}{l}\text { Domestic } \\
\text { mean }^{1}\end{array}$ & $\begin{array}{l}\text { Foreign } \\
\text { mean }^{1}\end{array}$ & $\begin{array}{l}\text { All } \\
\text { respondentsmean }\end{array}$ \\
\hline SWOT analysis & 2.914 & 3.909 & 3.072 \\
Critical success factors & 2.86 & 3.727 & 3.000 \\
Economic forecasting & 2.737 & 3.200 & 2.806 \\
Value chain analysis & 2.207 & 3.400 & 2.382 \\
PEST/step analysis & 2.158 & 2.818 & 2.265 \\
What-if analysis & 2.105 & 3.000 & 2.239 \\
Core capabilities analysis & 2.000 & 3.300 & 2.191 \\
Growth share matrix (BCG) & 1.948 & 3.222 & 2.119 \\
Porter's five forces analysis & 1.789 & 2.400 & 1.881
\end{tabular}

${ }^{1}$ The mean is an average on a scale of $1=$ not used to $5=$ always used 
Am. J. of Economics and Business Administration, 1 (2): 150-159, 2009

Table 8: Comparative characteristics of economies in transition

\begin{tabular}{|c|c|c|}
\hline & Underdeveloped & Developing \\
\hline Economy & $\begin{array}{l}\text { Mostly closed to foreign companies and somewhat } \\
\text { protected through regulations and governmental policies. }\end{array}$ & $\begin{array}{l}\text { Mostly open to entry by any firm (domestic and foreign) } \\
\text { and governmental policies which might support } \\
\text { competitive behaviors. }\end{array}$ \\
\hline Competition & $\begin{array}{l}\text { Very limited and in few sectors. Most industries/sectors } \\
\text { dominated by state owned enterprises. Localized } \\
\text { competition by privately owned firms. Internal market } \\
\text { focused company objectives. }\end{array}$ & $\begin{array}{l}\text { Government policies which support privatization of state } \\
\text { enterprises and development of competitive companies } \\
\text { in most industries/sectors. Export focused company } \\
\text { objectives. }\end{array}$ \\
\hline Foreign direct investment & $\begin{array}{l}\text { Very limited. May be encouraged with significant } \\
\text { ownership limitations. }\end{array}$ & $\begin{array}{l}\text { Increasingly high and very much encouraged. Regulatory } \\
\text { changes which support investments. }\end{array}$ \\
\hline Use of strategic process & $\begin{array}{l}\text { Ad-hoc strategies and lack of institutionalized formal } \\
\text { process used to develop competitive strategies. Annual } \\
\text { budgeting with possible multi-year forecast. Managers } \\
\text { forecast revenue, costs and capital needs a year in advance } \\
\text { and use these numbers to benchmark performance. }\end{array}$ & $\begin{array}{l}\text { Institutionalized formal process to develop company } \\
\text { strategies. Extensive use of multiyear forecasting (e.g., } \\
\text { trend analysis, regression models) and transition to } \\
\text { externally focused strategic planning (e.g. creative } \\
\text { of market trends, analyses customers and the competition). }\end{array}$ \\
\hline Management expertise & $\begin{array}{l}\text { Operational focus, with primary skills in organizational } \\
\text { processes (e.g., marketing and finance) or in } \\
\text { engineering (e.g. production). A very significant } \\
\text { majority of managers with undergraduate degrees, } \\
\text { in economics, business, or engineering fields. }\end{array}$ & $\begin{array}{l}\text { Strategic focus, with primary skills in conceptual and } \\
\text { broad based issues, ability to deal with continuous and } \\
\text { uncontrollable change and ambiguity. Executive } \\
\text { development programs, graduate degrees in business or } \\
\text { and ability to economics understand complexity of } \\
\text { multi-faceted competitive issues. }\end{array}$ \\
\hline
\end{tabular}

The earlier study ${ }^{[16]}$ did not have a question which directly addressed the organizational importance and frequency of the process. Therefore, we used "having a mission statement" (72.9\% of all firms) and "having a set of medium/long term objectives" (76.9\% of all firms) as indications of use of strategic process in the organizations in their sample ${ }^{[16]}$. In our study, $81.81 \%$ of all the firms stated that they consider strategic process as a priority organizational activity and undertake the activity annually. The differences are much greater if we look at their study subsamples (state-owned, local private and foreign) and compare their findings with ours.

As can be seen from Table 5, there have been significant increases in the acceptance and use of strategic processes from the earlier study time period (data seems to indicate 2002) to our study time period (data collected late 2007). These differences can be seen both in domestic and foreign firms. The earlier study population was drawn from a similar set of firms (large manufacturing enterprises) and included stateowned and privately-owned enterprises. Since all the firms in our study sample were privately owned, Table 5 only includes comparisons with privately owned firms in the earlier study sample.

When we look at the domestic firms with and without "business units", domestic firms with business units utilize the strategic analysis tools at a slightly greater frequency than domestic firms without business units. However, even with domestic firms with business units, there are high levels of usage differences between the foreign and domestic firms. For the domestic firms with business units, the most popular method was identified as the "critical success factors analysis", with $50.00 \%$ of respondents stating "frequent" or "always" use. In comparison, the percentages for business units of foreign firms and domestic firms without business units are 72.73 and $7.69 \%$, respectively. There were no "always" responses from domestic firms without a business unit. The most popular method for the domestic firms without any business units was "Economic Forecasting" with $28.57 \%$ responding with "frequently" or "always". In comparison, $44.44 \%$ of the domestic firms with a business unit responded with "frequently" and there were no "always" responses.

Furthermore, as can be seen from Table 6, even though our findings show a much greater attention to the competitive environment and its dynamics, the use of strategic and analytical tools is very limited and significantly lower in the domestic firms as compared to the subsidiaries of foreign firms. For the domestic firms participating in our study, the top three most popular (used frequently or always) strategy analysis and development tools were "critical success factors analysis" (38.60\%), "economic forecasting" (36.84\%) and "SWOT analysis" (36.21\%). Foreign based firms seemed to prefer "SWOT analysis" $(81.82 \%)$, "critical success factors analysis" (72.73\%) and "BCG growth share matrix analysis" (55.56\%). Table 7 details the usage frequency of different strategic analysis tools. The "frequency of use" response means (on a scale of $1=$ not used to 5 = always used) for "SWOT analysis" were 2.914 (domestic firms) and 3.909 (foreign firms) and for "critical success factors analysis" were 2.860 (domestic firms) and 3.727 (foreign firms). The mean response for the "Economic Forecasting" was 2.737 for domestic firms and 3.200 for foreign firms. Even though "BCG growth share 
matrix analysis" was used frequently or always by over half of the foreign firms, its popularity was not uniform among all foreign firm respondents. It was preceded by the mean response for the "value chain analysis", the third highest with 3.400 and by the mean for the "core capabilities analysis", the fourth highest with 3.300.

Present findings also show that the subsidiaries of foreign firms are much more focused on "contingency plans", $81.82 \%$ rating it high or very high, as compared to the domestic firms (holdings or subsidiaries), only $36.31 \%$ rating it high or very high. We can speculate on some alternative causes of the major focus discrepancy in "contingency planning". Among these alternative possibilities/reasons are "immediacy and intensity of competition" faced by these local market dependent firms, "better understanding of local issues" by the virtue of being homegrown and "degree of managerial sophistication" with the domestic firms still learning and developing sophisticated understanding of strategic issues.

\section{CONCLUSION}

Implications for management: Even though the findings show a significant increase in the importance and use of strategic tools and processes in Turkey, a transitional economy, they also show that there are continuing major differences in the use of these same tools and processes between competing firms from a transitional economy vs. a developed economy. The findings clearly show that the foreign owned firms adopt a broader and deeper repertoire of tools and techniques of strategic planning than do local firms and they tend to believe that the strategy process is more deliberate than do local firms. However, we are encouraged to see that there have been major positive changes since the earlier study and the local firms in our study have increasingly adopted the techniques and tools of strategic planning more commonly employed by foreign firms. Our study shows that the domestic firms have increasingly involved their top management in the process, allocated more resources to it and incorporated greater formality into the process. It is quite interesting to see that over time the importance of this organizational process in Turkish firms have come to more closely resemble those of foreign firms. We attribute these changes to increased competitive pressures brought upon these firms as the Turkish economy has opened up and free market forces have come into play as it has begun its transition from an underdeveloped economy to one that is developing. Table 8 presents a comparative list of characteristics associated with "underdeveloped" versus "developing" countries and the changes expected as the country moves from one stage on to the next.

According to Organization for Economic CoOperation and Development (OECD), Turkey's economic output increased by a third (with an average growth rate of $7.8 \%$ ) over the $2002-2005$ period, representing the strongest pace of growth among OECD countries. The country, in addition to being a recipient of Foreign Direct Investment (FDI), is also a significant investor in Central and Eastern Europe, with more than USD 1.5 billion invested. Furthermore, in the last two decades, Turkey's export mix has changed towards $\mathrm{mid} /$ high technology products, increasing from $5 \%$ in 1980 to $14 \%$ in 1990 and to $43 \%$ of total exports in 2005. An excellent representative of this trend is a very little known company called "Vestel Electronics". In addition to being a major player and a leading supplier, with a quarter of the market, of TVs in Europe, Vestel also supplies TVs to dozens of other companies, such as Sanyo and Hitachi, who re-label them under their own names. Therefore, we expect these changes and increased focus on the use of strategic tools and processes to continue as Turkey's market economy continues to develop and competition from foreign firms increase as globalization proceeds.

We propose that organizations have to go thorough dramatic changes in their business strategies and business models to survive in the competitive turbulence created by a country's transition from an underdeveloped to a developing stage. Changes in the government's foreign investment policy open the country to larger and more sophisticated direct competitors, negate the existing protections of the local markets and create major threats for the local businesses. These outcomes are clearly identified through the findings of research, albeit few, in this area. Our findings also show similar results and further identify the level of changes, as the transition of the economy continues over time. Never the less, there are lessons for managers and investors, who pursue business opportunities in these transitory environments. Findings clearly show that the managerial skills and competitive processes used by the domestic organizations are evolving and will create significant competitive challenges for the new entrants into these environments.

Directions for future research: While the findings of this study provide a contribution to our understanding of the nature and practice of strategic planning in Turkish companies, there are a number of potential areas for future research. First, it would be a useful contribution to investigate the use of planning 
techniques and the pervasiveness of the process in service organizations (all the firms in our sample were manufacturing firms) and broaden the study sample by focusing on second-tier companies (our sample was drawn from the top 500 firms list of Istanbul Chamber of Industry). Another area of future research would be to examine the relationship between strategic planning and organizational performance. There has been an ongoing interest in this research area in developing economies. However, our preliminary search has produced no such corresponding research in developing economies.

Limitations of the study: This study is one of the few studies to examine the strategic planning process in a sample of firms from a transitional economy. It can also be considered a longitudinal study because it examines a similar set of institutions in the same country to identify any changes in the degree and frequency of use of strategic tools over a 5 year time span. Inclusion of domestic and foreign-owned firms in the study provides yet another perspective to understanding the differences in the use of strategic tools and processes between developed and developing country based firms. Unfortunately, the sample size of the study (number of respondents) is small and is composed of large scale manufacturing firms. As a result, we cannot make broad based conclusive statements. Even though the ranking of the responding firms ranged from 2-497 (out of 500 firms receiving the questionnaire), there could also be some respondent bias. There is a possibility that more successful/active firms responded to the survey, which will make the sample even less representative.

\section{REFERENCES}

1. Mintzberg, H. and J.A. Waters, 1985. Of strategies, deliberate and emergent. Strategic Management. J., 6: 257-272. DOI: 10.1002/smj.4250060306

2. Fredrickson, J.W. and T.R. Mitchell, 1984. Strategic decision processes: Extension, observations, future directions. Acad. Manage. J., 27: 399-423.

3. Hayes, R.H. and W.J. Abernathy, 1980. Managing our way to economic decline. Harvard Bus. Rev., 58: 67-77. DOI: 10.1225/80405

4. Foss, J.N., 1997. Resources and Strategy: A Brief Overview of Themes and Contributions. In: Resources, Firms and Strategies, Foss, J.N. (Ed.). Oxford University Press, Oxford. ISBN: 0198781792, pp: 100-127.
5. Barney, J.B., 1991. Firm resources and sustained competitive advantage. J. Manage., 17: 99-120. DOI: $10.1177 / 014920639101700108$

6. Grant, R.M., 1991. The resource-based theory of competitive advantage: Implications for strategy formulation. California Manage. Rev., 33: 114-135.

7. Glaister, K.W. and J.R. Falshaw, 1999. Strategic planning: Still going strong? Long Range Plan., 32: 107-116. DOI: 10.1016/S0024-6301(98)00131-9

8. Gooderham, G., 1998. Debunking the myths of strategic planning. CMA Mag., 72: 24-26.

9. Mintzberg, H., 1994. The fall and rise of strategic planning. Harvard Bus. Rev., 72: 107-114. DOI: 10.1225/94107

10. Porter, M.E., K. Schwab, A. Lopez-Claros and X. Sala-i-Martin, 2006. The Global Competitiveness Report 2006-2007. Palgrave Macmillan, New York, ISBN: 1403996369, pp: 608.

11. Porter, M.E., 2007. November. The global competitiveness report 2007-2008. Palgrave Macmillian, New York, ISBN: 1403996377.

12. Garten, J.E., 1996. The big emerging markets. Columbia J. World Bus., 31: 7-31. DOI: 10.1016/S0022-5428(96)90020-4

13. Khan, G.M. and E. Ali-Buarki, 1992. Strategic planning in Bahrain. Manage. Dec., 30: 3-9. DOI: 10.1108/00251749210015599

14. Dansoh, A., 2005. Strategic planning practice of construction firms in Ghana. Construct. Manage. Econ., 23: 163-168. DOI: $10.1080 / 0144619042000241435$

15. Ghamdi, S.M.A., 2005. The use of strategic planning tools and techniques in Saudi Arabia: An empirical study. Intl. J. Manage., 22: 376-395.

16. Dincer, O., E. Tatoglu and K.W. Glaister, 2006. The strategic planning process: Evidence from Turkish firms. Manage. Res. News, 29: 206-219. DOI: $10.1108 / 1409170610665068$ 